\title{
Cambial variations of Piper (Piperaceae) in Taiwan
}

\author{
Sheng-Zehn Yang ${ }^{*}$ and Po-Hao Chen
}

\begin{abstract}
Background: Cambial variations in lianas of Piperaceae in Taiwan have not been studied previously. The stem anatomy of seven Piper species from Taiwan was examined to document cambial variations and better distinguish the species when leaves are absent.

Results: A key for the seven species is provided, based on the internal stem anatomy. The seven Piper species climb via adventitious roots, and in cross section, the stems were generally eccentric and oblate, although a transversely elliptic stem was found in P. kadsura (Choisy) Ohwi and P. sintenense Hatus. A cambial variant with secondary growth of external primary vascular bundles and xylem in plates was observed in all species except Piper betle L., which developed another cambium variant with xylem furrowed deeply by parenchyma proliferation. The sclerenchymatous ring surrounding the medullary vascular bundles was always continuous except in P. betle, where it was discontinuous. Mucilage canals varied from absent to present in the center of the pith, or present in the pith and inner cortex. Different sizes of vessels dispersed throughout the stem were ring or diffuse porous. The numbers of medullary and peripheral vascular bundles were distinctive and the widths of rays were noticeably different in each species. Differences in the growth rate of the medullary vascular bundles produced two development types of vascular bundles, although in both types, the peripheral vascular bundles gradually lengthen and become separated from each other by wide rays.

Conclusions: We documented the internal stem anatomy of six previously unstudied species of Piper, including three endemic species, P. kwashoense Hayata, P. sintenense, and P. taiwanense Lin and Lu, and found that P. betle had deeply furrowed xylem, which had not been reported for the species before. The descriptions and photographs of seven Piper species will also provide a basis for further morphological studies.
\end{abstract}

Keywords: Cortical vascular bundle, Liana, Mucilage canal, Piperaceae, Stem anatomy

\section{Background}

Lianas usually have two stages of development, the autologous support stage and the climbing stage (Schnitzer and Bongers 2002). Internally, the autologous support stage is characterized by a few narrow vessels and many thick fibers. The climbing stage involves secondary growth of the stem, which can be a standard or anomalous (Isnard and Silk 2009). Morphological variation in liana stems is primarily associated with the geometry of the phloem and xylem, and irregular shapes within the stems are classified into cambial variants (Angyalossy et al. 2015). The diversity of liana stem shapes, structures,

*Correspondence: yangsz@mail.npust.edu.tw

National Pingtung University of Science and Technology, No. 1, Shuefu Rd., Neipu, Pingtung 912, Taiwan, ROC and cambial variants has been recently reviewed (Angyalossy et al. 2012), including those of Piperaceae.

Members of Piperaceae represent about five genera and 3700 species around the world (Christenhusz and Byng 2016), and many are economically important because of their medicinal and culinary uses. They are erect or scandent shrubs, small trees, or succulent, terrestrial herbs, with nodose stems. The leaves are entire, alternate to opposite or verticillate, petiolate or infrequently subsessile, palmately nerved or penninerved, pellucid dotted, and sometime aromatic (Souza et al. 2004). The genus Piper L. is represented by about 1050 species distributed primarily in the tropics (Mabberley 2008). The most outstanding anatomical character in the Piperaceae is the nature of the vascular bundles in the stem. In all 
species of Piperaceae studied to date in the genera Piper, Manekia Trel., and Zippelia Blume, vascular bundles are organized in two or more concentric rings, a characteristic that is not present in other genera in Piperaceae (Trueba et al. 2015).

Several studies have characterized cambial variants in certain Piper species. Piper obtusilimbum C. DC. has a typical arrangement of tissues (Tepe et al. 2007), with a parenchymatous pith, medullary vascular bundles, a sclerenchymatous cylinder, peripheral vascular bundles, and a vascular cambium. The stem of Piper betle $\mathrm{L}$. had an inner irregular circle of primary vascular bundles interspersed with a large mucilage canal in the pith, more mucilage canals in the inner cortex, an undulating wall of sclerenchyma, and an outer ring of smaller cortical bundles. The primary vascular (medullary) bundles occupied the pith (Beck 2011). Raman et al. (2012) showed that the stem of $P$. betle has a ring of mucilage canals located between cortical and medullary rings of primary vascular bundles, a central mucilage canal in the pith, secretory cells in the cortex, cortical fibers, and an endodermis with a Casparian strip. The descriptions of $P$. betle here do not match each other owing to the age of the stem. Beck (2011) showed that the stem of P. excelsum G. Forst. had two medullary bundles that occupied the very center of the pith. The species had two cylinders of vascular bundles. The central, irregularly grouped primary vascular bundles were enclosed by a thick cylinder of secondary xylem capped by phloem that is separated by wider medullary rays of primary parenchyma.

Raman et al. (2012) studied P. sarmentosum Roxb. The stem of Piper sarmentosum has a large central mucilage canal, medullary vascular bundles surrounded by parenchyma in the pith, a ring of cortical vascular bundles, and a discontinuous ring of collenchyma in the outer cortex. Saraswathy et al. (2013) indicated that the stem of $P$. retrofractum Vahl. was circular in cross section, with a large central mucilage canal surrounded by individual bundles scattered in a parenchymatous cortex, which was encircled by a wavy ring of sclerenchyma followed by a ring of vascular bundles and medullary rays. A pericycle and collenchyma formed the outer cortex. In a broader study of woodiness in Piperales and Trueba et al. (2015) presented images of transverse sections of $P$. gorgonillense Trel. and Yunck. and P. nudibracteatum C. DC. Piper gorgonillense produced wide, lignified rays, with solitary or clustered vessels, but the center and edge of the stem were not included. A growth ring was visible in the rays and vascular tissue. The peripheral vascular bundles in Piper nudibracteatum gradually elongated through secondary growth, exceeding the medullary vascular bundles, while the growth of the medullary bundles was minimal, and wide rays were formed by primary parenchyma cells.
Santos et al. (2015) showed that in P. amalago L., a large parenchymatous pith is surrounded by an inner circle of approximately nine medullary bundles, a ring of sclerenchymatous fibers, and an outer circle of approximately 30 vascular bundles, some of which have bundles of fiber capping the adjoining phloem.

According to these studies and others, Piper typically has an inner series of vascular bundles separated from an outer series by a sclerenchymatous ring. This pattern has been observed in $P$. nigrum L. and $P$. colubrinum Link (Ravindran and Remarshree 1998); P. diospyrifolium Kunth (Souza et al. 2004); P. amalago, P. betle, Piper excelsum, Piper gorgonillense, P. nudibracteatum, Piper obtusilimbum, P. retrofractum, P. sarmentosum, $P$. regnelli (Miq.) C. DC. (Pessini et al. 2003); P. gaudichaudianum Kunth (Albiero et al. 2005b); P. crassinervium Kunth (Albiero et al. 2005a); P. hispidum Sw. (Albiero et al. 2006); P. arboretum (Souza et al. 2009); and P. mikanianum (Kunth) Steud. (Duarte and Siebenrock 2010).

Taiwan is located in the subtropical zone, with a warm and humid climate. Piperaceae are represented in Taiwan by two genera, Peperomia Ruiz and Pavon and Piper. Eight scandent species and two herbs are recorded in the genus Piper (Lin and Lu 1996; Hsu and Chung 2016). However, data regarding the internal stem anatomy of seven of the climbing species are lacking. Cambial variations are diverse within the family, so the present study attempts to (1) provide detailed photographs of features discussed, (2) specify the developmental stages observed, and (3) provide a key based on anatomical characters of transverse sections to facilitate the identification of irregular cambial activity in lianescent species of the genus Piper in Taiwan.

\section{Methods}

From 2014 to 2016, we collected multiple samples of seven Piper species, which are extensively distributed in the low mountainous forests of Taiwan. Species, collecting localities, voucher numbers, and the maximum and minimum stem diameters are presented in Table 1. Stems with a lignified epidermis were selected to compare and identify the structural variations using the obvious secondary growth characteristics in their cross sections. For each species only one sample, with obvious cambial variations that were easy to observe, was selected for photos and description. The species $P$. interruptum Opiz var. multinervum C. DC. was not included in this present study because the collected stem was too small and without obvious cambial structure. The developmental stages of vascular bundles in P. betle and Piper kadsura were observed with particular care because the fleshy materials we collected included different stem sizes for these two species. 
Table 1 Piper species examined for this study

\begin{tabular}{|c|c|c|c|c|}
\hline Species & Collection localities & $\begin{array}{l}\text { Herbarium and } \\
\text { voucher numbers }\end{array}$ & $\begin{array}{l}\text { Minimum } \\
\text { diameter }(\mathrm{mm})\end{array}$ & $\begin{array}{l}\text { Maximum } \\
\text { diameter }(\mathrm{mm})\end{array}$ \\
\hline Piper arborescens Roxb. & Lanyu, Taitung County & PPI77234 & 3.9 & 5.5 \\
\hline Piper betle L. & Lilongshan, Taiwu, Pingtung County & PPI76665 & 3.5 & 32.0 \\
\hline Piper kadsura (Choisy) Ohwi & $\begin{array}{l}\text { Liangshan, Machia, Pauli, Pingtung } \\
\text { County }\end{array}$ & PPI61858 & 2.5 & 15.4 \\
\hline Piper kawakamii Hayata & Hsiaoliouchiou, Pingtung County & PPI63612 & 7.8 & 7.8 \\
\hline Piper kwashoense Hayata ${ }^{a}$ & Lanyu, Taitung County & PPI19807 & 6.1 & 9.8 \\
\hline Piper sintenense Hatusima ${ }^{a}$ & Tajen, Taitung County & PPI60014 & 2.1 & 4.8 \\
\hline Piper taiwanense Lin and $\mathrm{Lu}^{\mathrm{a}}$ & $\begin{array}{l}\text { Liangshan, Machia, Pauli, Pingtung } \\
\text { County }\end{array}$ & PPI79479 & 8.5 & 15.4 \\
\hline
\end{tabular}

a Endemic to Taiwan and distributed at low altitudes

Fresh stems were cut into pieces about $5 \mathrm{~cm}$ long, and a freehand cross section of each stem was made with a razor blade. The stem surface was immediately photographed using a Nikon D7100 SLR digital camera (Lens AF Micro Nikon $60 \mathrm{~mm}$ 1:2.8D, Nikon Corporation, Tokyo, Japan), and qualitative and quantitative anatomical traits were determined using Image-J software (Ferreira and Rasband 2011). The specimens were dried in an oven $\left(60^{\circ} \mathrm{C}\right)$ for $4-5$ days and were then stored at $-40{ }^{\circ} \mathrm{C}$ for $3-4$ days. All specimens were deposited in the Provincial Pingtung Institute (PPI) herbarium at the National Pingtung University of Science and Technology, Pingtung, Taiwan, for subsequent identification. The nomenclature follows Flora of Taiwan Volume 2 (Lin and Lu 1996).

The stem anatomy of P. betle and Piper kwashoense has been reported in earlier studies (Raman et al. 2012; Yang and Chen 2015), but all photographs and observations presented in this study are new. The climbing mechanisms of the lianas (adhesive, hook, or twining) follow Chen et al. (2013). Terminology for the description follows Chiang (Chiang 1973), Metcalfe and Chalk (1979, 1985), Tepe et al. (2007), Beck (2011), Raman et al. (2012), Saraswathy et al. (2013), and Santos et al. (2015) (see Additional file 1: Appendix), and the stem shape determined by a length/width ratio of between 1.5 and 2.0 followed the Systematic Association Committee for Descriptive Terminology (1962).

\section{Results}

The anatomical characteristics of the stems are described in Table 2 and shown in the figures as follows: Piper arborescens (Fig. 1a), P. betle (Figs. 1b, c, 2a-d), P. kadsura (Figs. 1d, 2e-h), Piper kawakamii (Fig. 1e), P. kwashoense (Fig. 1f), Piper sintenense (Fig. 1g), and Piper taiwanense (Fig. 1h). The stem shape was generally eccentric to oblate or transversely elliptic in cross section due to differential amounts of xylem deposition (following
Carlquist 1991). The number of medullary vascular bundles or peripheral vascular bundles varied among species, from approximately 4-7 medullary vascular bundles in P. sintenense (Fig. 1g) to 12-19 in P. betle (Fig. 1b, c) and approximately 15-23 peripheral vascular bundles in P. kadsura (Fig. 1d) and P. sintenense (Fig. 1g) to 34-41 in P. kwashoense (Fig. 1f). Vessels of different sizes are dispersed throughout the stem and there is no obvious arrangement of vessels in the secondary xylem, so we suggest that they can be classified as ring porous and diffuse porous following Beck (2011).

The vessel arrangement in the secondary xylem was diffuse porous in P. arborescens (Fig. 1a), and ring porous in P. kawakamii (Fig. 1e). A ring of sclerenchyma separated the rings of medullary vascular bundles and peripheral vascular bundles and was continuous in all species except P. betle (Fig. 1c). P. betle developed a deeply furrowed xylem cambial variant by parenchyma proliferation, which is not found in the other six species. The mucilage canals varied from absent (P. sintenense and $P$. taiwanense) to present in the center of the pith (P. arborescens, $P$. kadsura, $P$. kawakamii, and $P$. kwashoense; Fig. 1a, d-f) or present in the pith and inner cortex (P. betle; Fig. 2a). The maximum and minimum width of rays differed from each other in all species except $P$. sintenense, which had rays of a uniform width (Fig. 1g). The medullary vascular bundles persist but their growth is eventually minimal, while the peripheral vascular bundles continue to develop as the stem increases in diameter, and secondary thickening is restricted to the peripheral vascular bundles (Fig. 2a-d) due to the fascicular cambia that are located between the phloem and xylem of the peripheral vascular bundles.

By comparing different sizes of stems in $P$. betle (Fig. 2a-d) and P. kadsura (Fig. 2e-h), two different series of vascular bundle development were observed. In the first type of development, much of the stem's volume is parenchyma, with one central mucilage canal is located in the pith, and eight additional mucilage canals in the inner 
Table 2 Anatomical characteristics of Piper stems in Taiwan (transverse sections)

\begin{tabular}{|c|c|c|c|c|c|c|c|}
\hline Characteristic & $\begin{array}{l}\text { Piper } \\
\text { arborescens }\end{array}$ & P. betle & P. kadsura & P. kawakamii & P. kwashoense & P. sintenense & P. taiwanense \\
\hline Shape & Oblate & Oblate & $\begin{array}{l}\text { Transversely } \\
\text { elliptica }\end{array}$ & Oblate & Oblate & $\begin{array}{l}\text { Transversely } \\
\text { elliptica }\end{array}$ & Oblate \\
\hline Phloem bundles & Arcuate & $\begin{array}{l}\text { Rounded-elon- } \\
\text { gate }\end{array}$ & Triangular & Arcuate & Arcuate & Arcuate & $\begin{array}{l}\text { Rectangular to } \\
\text { triangular }\end{array}$ \\
\hline Mvb number & $9-13$ & $12-19$ & $5-11$ & $6-7$ & $12-14$ & $4-7$ & $6-9$ \\
\hline Pvb number & $30-31$ & $30-40$ & $15-23$ & $21-22$ & $34-41$ & $16-23$ & $21-26$ \\
\hline Ray width ( $\mu \mathrm{m})$ & $37-251$ & $129-617$ & $55-493$ & $38-603$ & $80-294$ & $106-276$ & $66-342$ \\
\hline Vessel diameter $(\mu \mathrm{m})$ & $4-128$ & $18-217$ & $9-125$ & $10-167$ & $10-145$ & $7-100$ & $6-197$ \\
\hline Vessel arrangement & 2 & 2 & 2 & 1 & 1 & 2 & 1 \\
\hline Sclerenchyma ring & 1 & 0 & 1 & 1 & 1 & 1 & 1 \\
\hline Furrowed xylem & 0 & 1 & 0 & 0 & 0 & 0 & 0 \\
\hline $\begin{array}{l}\text { Parenchyma prolif- } \\
\text { eration }\end{array}$ & 0 & 1 & 1 & 0 & 0 & 1 & 1 \\
\hline $\mathrm{Mc}$ & 1 & 1 & 1 & 1 & 1 & 0 & 0 \\
\hline $\begin{array}{l}\text { Mc dispersed in } \\
\text { cortex }\end{array}$ & 0 & 1 & 0 & 0 & 0 & 0 & 0 \\
\hline Central mc in pith & 1 & 1 & 1 & 1 & 1 & 0 & 0 \\
\hline Pericycle & 1 & 0 & 0 & 0 & 1 & 0 & 1 \\
\hline
\end{tabular}

$m v b$ medullary vascular bundles, pvb peripheral vascular bundles, vessel arrangement: 1 ring-porous secondary xylem, 2 diffuse-porous secondary xylem; sclerenchyma ring, 0 discontinuous, 1 continuous; furrowed xylem: 0 absent, 1 present; parenchyma proliferation, 0 absent, 1 present; $m c$ mucilage canals, 0 absent, 1 present; mc in cortex: 0 absent, 1 present; central mc: 0 absent, 1 present; pericycle: 0 absent, 1 present

cortex (Fig. 2a). The medullary vascular bundles experience secondary growth from a fascicular cambium until they reach a certain size, while the number of medullary vascular bundles increases (Fig. 2b), the cortical vascular bundles do not grow appreciably, and a sclerenchymatous ring thickens (Fig. 2c). Then the growth of medullary vascular bundles is essentially minimal, while the peripheral vascular bundles produce xylem and phloem from a fascicular cambium, eventually exceeding the medullary vascular bundles, and wide rays fully separate the sclerenchymatous ring, which becomes discontinuous (Fig. 2d). The species $P$. betle showed this type of development.

In the second type of development, much of the stem's volume is also parenchyma, and only one mucilage canal is present, located in the center of the pith (Fig. 2e). Approximately ten medullary vascular bundles and a sclerenchymatous ring are in the inner cortex, and all the cortical vascular bundles apparently develop. Both medullary vascular bundles and cortical vascular bundles continue to grow (Fig. 2f), and a ring of sclerenchyma gradually forms (Fig. 2g). Then, the growth of medullary vascular bundles becomes minimal, while the peripheral vascular bundles continuously grow from a fascicular cambium. The medullary vascular bundles scarcely change while the peripheral vascular bundles soon exceed the medullary vascular bundles (Fig. 2h), wide rays fully develop, and the sclerenchymatous ring remains continuous. The species $P$. kadsura belongs to this type.
The epidermis was one of the diagnostic features for identifying these lianescent species. P. betle had noticeable corky ridges (periderm) (Fig. 1b, c) on larger stems, and this characteristic was not found in the other six species. All seven Piper species climb via adventitious roots. Based on the characteristics of the stem transverse sections, we established a key to the seven climbing species, allowing species identification when leaves are not present.

\begin{tabular}{|c|c|c|}
\hline 1. & $\begin{array}{l}\text { Sclerenchymatous ring discontinuous; } \\
\text { ring of mucilage canals in the cortex }\end{array}$ & P. betle \\
\hline-1 & $\begin{array}{l}\text { Sclerenchymatous ring continuous; } \\
\text { mucilage canals central only or absent }\end{array}$ & 2. \\
\hline 2. & Mucilage canals absent & 3. \\
\hline-2 & Mucilage canals in the center of the pith & 4. \\
\hline 3. & $\begin{array}{l}\text { Phloem rectangular to triangular; } \\
\text { stem transverse section oblate }\end{array}$ & P.taiwanense \\
\hline-3 & $\begin{array}{l}\text { Phloem arcuate; stem transverse } \\
\text { section transversely elliptic }\end{array}$ & P. sintenense \\
\hline 4. & Phloem triangular & P. kadsura \\
\hline-4 & Phloem arcuate & 5. \\
\hline 5. & $\begin{array}{l}\text { Number of medullary vascular bundles } \\
\text { approximately } 6-7\end{array}$ & P. kawakamii \\
\hline-5 & Number of medullary vascular bundles $>8$ & 6. \\
\hline 6. & $\begin{array}{l}\text { Peripheral vascular bundles approximately } \\
\text { 30-31, secondary xylem with, diffuse-porous } \\
\text { vessels }\end{array}$ & P. arborescens \\
\hline-6 & $\begin{array}{l}\text { Peripheral vascular bundles approximately } \\
\text { 34-41, secondary xylem with ring-porous } \\
\text { vessels }\end{array}$ & P. kwashoense \\
\hline
\end{tabular}



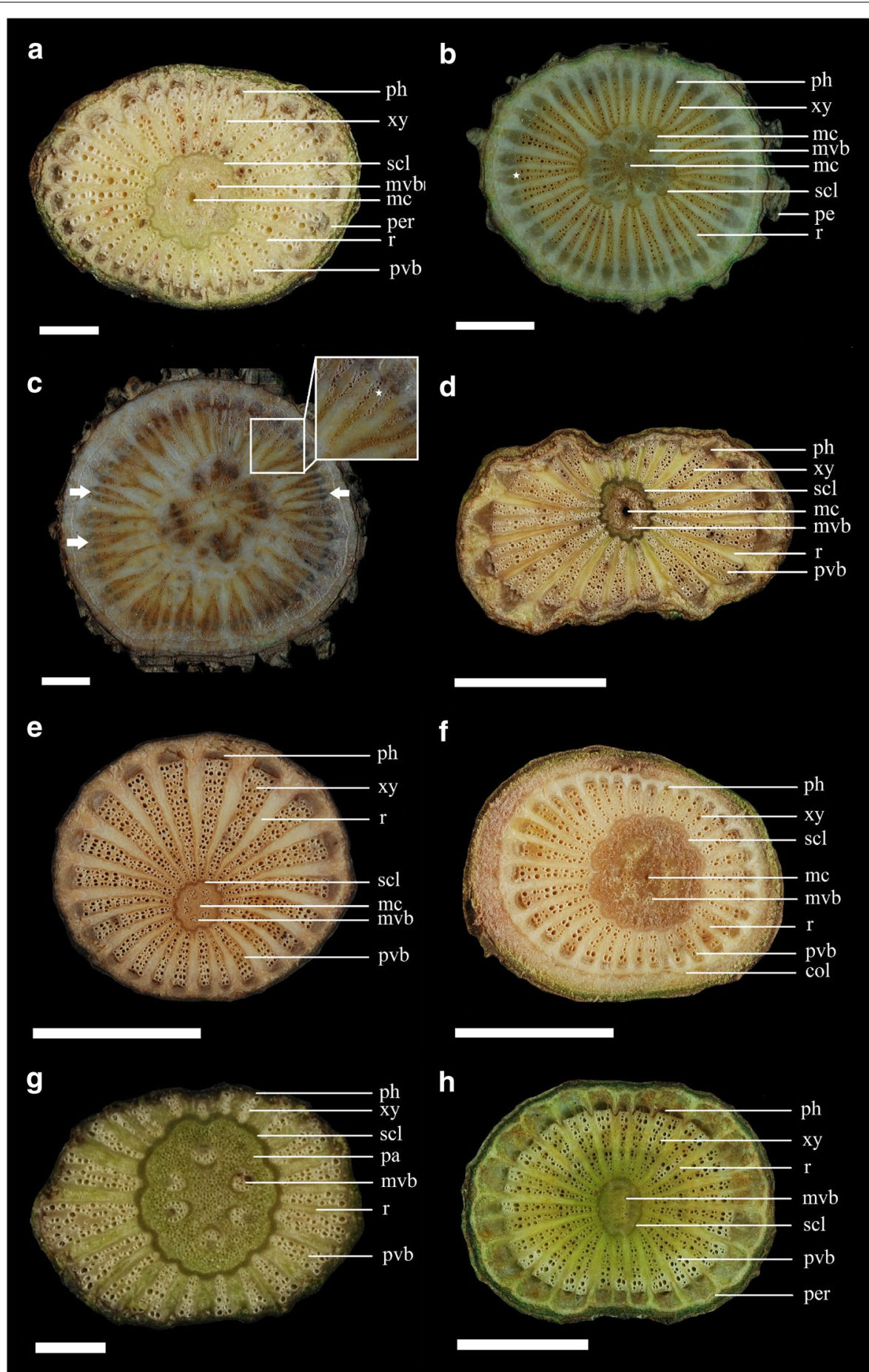

Fig. 1 Stem transverse sections of seven Piper species. a P. arborescens, showing only one mucilage canal (mc) in the center of the pith, surrounded by nine medullary vascular bundles (mvb), a continuous sclerenchyma (scl) ring separating the two cycles of vascular bundles, and wide rays ( $r$ ) separating the peripheral vascular bundles (pvb); approximately $30 \mathrm{pvb}$; pericycle (per) surrounding the phloem (ph). b, c P. betle. b Showing discontinuous scl ring, secondary growth of the mvb and pvb approximately $17 \mathrm{mvb}$ and 37 pvb; periderm (pe) thick and grooved. $\mathbf{c}$ Deeply furrowed xylem (arrowhead) by secondary parenchyma proliferation (white star); approximately $13 \mathrm{mvb}$ and 31 pvb, and rays become wider, separating the pvb. d $P$. kadsura, showing triangular phloem (ph), and rays (r) which composed of secondary parenchyma; approximately 8 mvb, and 21 pvb. e $P$. kawakamii, showing approximately $7 \mathrm{mvb}$, and $22 \mathrm{pvb}$ separated by wide rays ( $r$ ). f $P$. kwashoense, approximately $12 \mathrm{mvb}$ and $34 \mathrm{pvb}$, and collenchyma (col) ring surrounding the peripheral regions. $\mathbf{g}$. sintenense, showing parenchyma (pa) occupying much of the pith volume, approximately $6 \mathrm{mvb}$ and $22 \mathrm{pvb}$. $\mathbf{h}$ P. taiwanense, showing approximately $8-9 \mathrm{mvb}, 21-26 \mathrm{pvb}$, and pericycle (per) surrounded the phloem (ph). Scale: Scale $\mathbf{a}=1 \mathrm{~mm} ; \mathbf{b}-\mathbf{d}=5 \mathrm{~mm} ; \mathbf{e}, \mathbf{f}, \mathbf{h}=5 \mathrm{~mm} ; \mathbf{g}=1 \mathrm{~mm}$ 


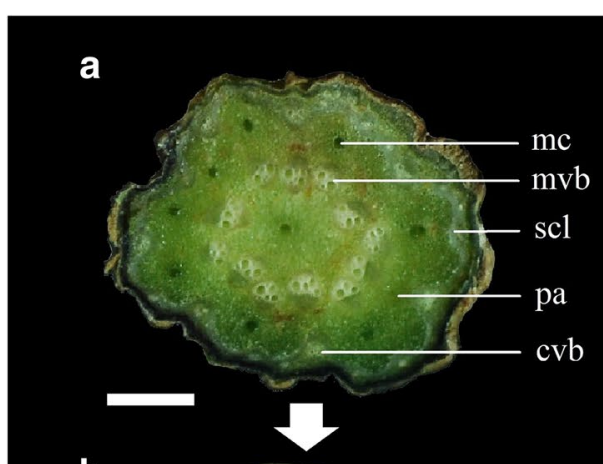

b

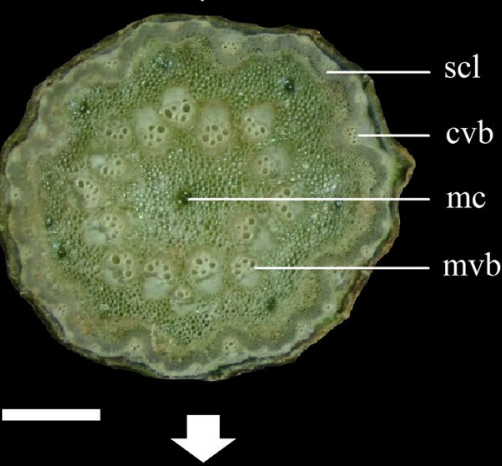

c

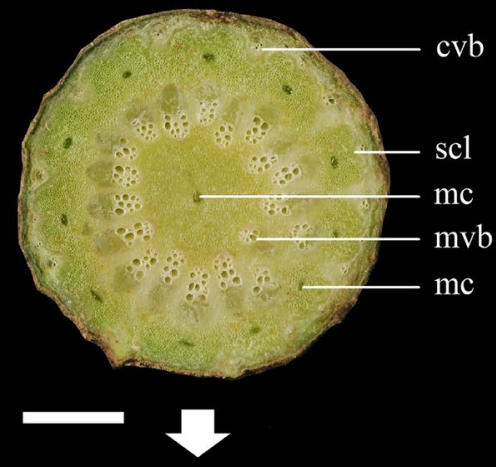

d

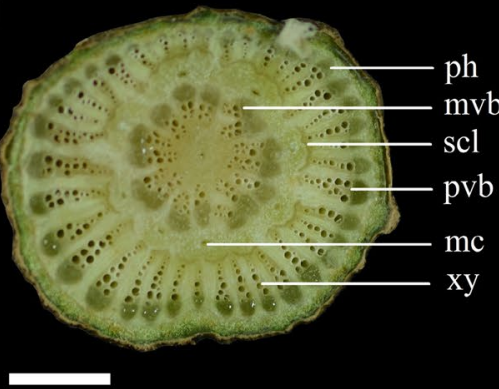

e

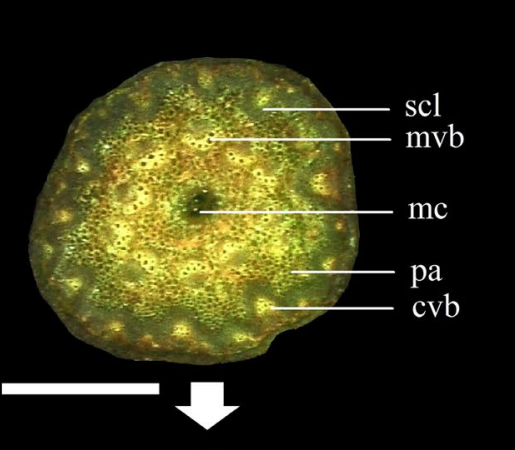

f

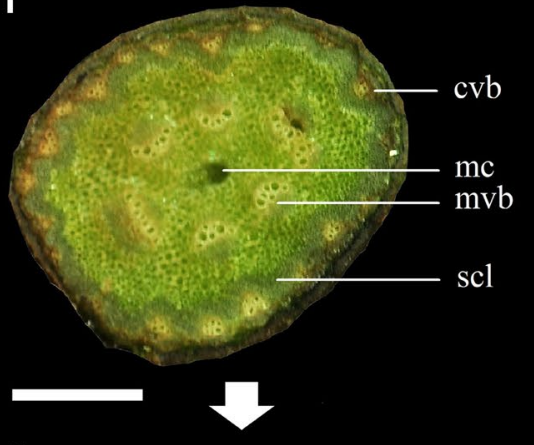

g

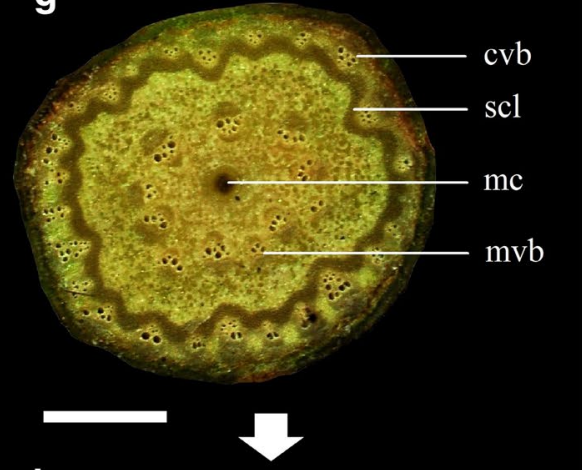

h

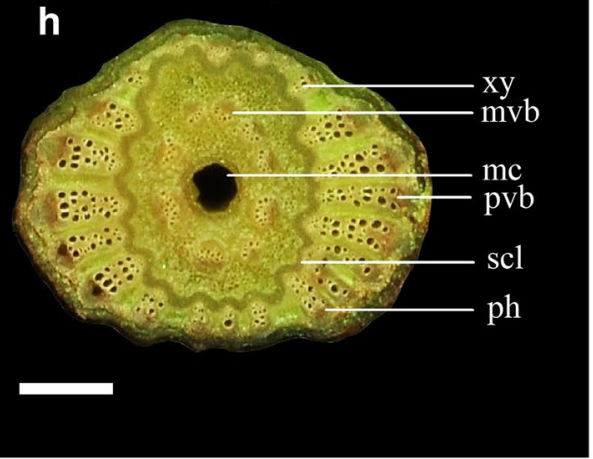

Fig. 2 Two development types in Piper in Taiwan. a-d Stem transverse sections of development stages in P. betle. a The pith surrounded by approximately 12 medullary vascular bundles ( $\mathrm{mvb}$ ), a ring of sclerenchyma (scl), and an indistinct number of cortical vascular bundles (cvb) in the outer cortex. $\mathbf{b}$ The mvb increase in number, approximately $19 \mathrm{mvb}$ and an indistinct number of $\mathrm{cvb}$. $\mathbf{c}$ The ring of scl begins to separate as the wide rays of secondary parenchyma are initiated, an indistinct number of $\mathrm{cvb}$ in the outer cortex. $\mathbf{d}$ Approximately 18 mvb and 38 peripheral vascular bundles (pvb), mc in the outer cortex, and showing rounded-elongate phloem (ph) and vessels of xylem (xy). e-h Stem transverse sections of development stages in P. kadsura. e Approximately $10 \mathrm{mvb}$ and a ring of scl, and the cvb develop apparently. f Both mvb and cvb continue to grow, approximately $7 \mathrm{mvb}, 20 \mathrm{cvb}$. $\mathbf{g}$ The scl ring appears apparently, and secondary production is limited to the cvb, approximately $11 \mathrm{mvb}$ and $24 \mathrm{cvb}$. h Approximately $9 \mathrm{mvb}$ and $22 \mathrm{pvb}$, all the pvb continue to grow, and become longer than the mvb in length, and showing triangular phloem (ph) and vessels of xylem (xy). Scale $\mathbf{a}, \mathbf{b}, \mathbf{e}$ to $\mathbf{h}=1 \mathrm{~mm} ; \mathbf{c}, \mathbf{d}=2 \mathrm{~mm}$ 


\section{Discussion}

Cambial variants of liana stems are divided into two types: those that originate from a single cambium and those from multiple cambia (Angyalossy et al. 2012). Members of Piperaceae such as Manekia obtusa (Miq.) T. Arias, Callejas and Bornst produce the external vascular cylinders type (Angyalossy et al. 2015); in the present study, all seven Piper species also developed two series of primary vascular bundles separated by a ring of sclerenchyma. The outer irregular series of primary vascular bundles, or cortical vascular bundles, always developed near the cortex or periderm. The inner irregular series of vascular bundles, the medullary vascular bundles, were always found around the center of the stem. The stem of $P$. gorgonillense produced wide, lignified rays, with solitary or clustered vessels (Trueba et al. 2015), and the stem of $P$. sarmentosum has a discontinuous ring of collenchyma in the outer cortex (Raman et al. 2012); these characteristics were not observed in this study. The stem of $P$. obtusilimbum has a typical arrangement of tissues (Tepe et al. 2007), but lacks mucilage canals in the pith or in the inner cortex.

The stem of $P$. excelsum had also two cylinders of vascular bundles, but two medullary bundles, rather than a mucilage canal, occupied the very center of the pith (Beck 2011). The characteristic of a thick cylinder of tracheary elements that formed radially extended regions from cambium activity in P. excelsum (Beck 2011), P. amalago (Santos et al. 2015), and $P$. nudibracteatum (Trueba et al. 2015) was also seen in P. kadsura. The stem of P. retrofractum was circular in transverse section (Saraswathy et al. 2013), unlike the oblate, transversely elliptical stems of the seven species in the present study.

The stem of $P$. betle has a ring of mucilage canals located between the cortical and medullary rings of primary vascular bundles (Raman et al. 2012); in this study, eight additional mucilage canals were found in the inner cortex. The stem of $P$. kadsura just has a central mucilage canal in the pith, as described in P. excelsum by Beck (2011). Though we did not observe the development process of the other five species in Taiwan, the two diagnostic features, a continuous sclerenchymatous ring and only a central mucilage canal (see Table 2), were also found in the these species, indicating that their development process is similar to that of P. kadsura. However, the development of the other five species was not observed, and although the two diagnostic features were the same, further study is needed to confirm that the same pattern of development occurs.

We observed that the growth of medullary vascular bundles continues but gradually becomes minimal, while the peripheral vascular bundles continue to grow in these seven Piper species. This result is consistent with a previous report (Trueba et al. 2015) that secondary thickening is actually restricted to the peripheral vascular bundles in species undergoing secondary growth. The variations in the activity of the medullary vascular bundles and the peripheral vascular bundles result in unusual distribution patterns of xylem and phloem, which influences stem shape based on the shape of the peripheral vascular bundles (Beck 2011). The function of the flattened stems of lianas is related to their climbing habit, where they are either appressed to or leaning on the supporting tree's trunk; this habit is entirely restricted in epiphytic lianas (Obaton 1960). The seven Piper species climb via adventitious roots and form a cambial variant type with flattened stems or oblate in that the broad face of the flattened axis contacts branches of trees (Carlquist 2001). The flattened stems as well as adventitious roots seem related to an epiphytic habit. More than two vascular bundle rings or two development types might be seen in stem of larger diameter, so it is valuable to observe more details in further studies.

Cambial variants in Piperaceae include successive cambia, xylem in plates, xylem dispersed by parenchyma divisions, intraxylary phloem, included phloem (interxylary phloem), phloem arcs/wedges, and secondary growth of external primary vascular bundles (Metcalfe and Chalk 1985; Caballé 1993; Carlquist 1991, 2001, 2013; Isnard et al. 2003; Acevedo-Rodríguez 2005; Jacques and de Franceschi 2007; Angyalossy et al. 2012). In woody vines, certain segments of the interfascicular cambium produce secondary parenchyma whereas a fascicular cambium produces typical proportions of xylem and phloem, as in Aristolochia (Aristolochiaceae) (Beck 2011). The xylem is furrowed by arcs or wedges of phloem derived from portions of the cambium that produce less xylem and more phloem (Angyalossy et al. 2015). However, furrowed xylem may develop from phloem wedges or secondary parenchyma proliferation. Carlquist (1991) defined rays as having very wide, thin-walled cells with limited subdivision during secondary growth. Wide rays develop in Piperaceae, and during secondary growth, the rays do not subdivide very much. Indeed, there may be little difference between them. Wider rays in lianas allow the stems to experience torsion without sustaining damage to vessels and contribute to liana stem flexibility (Putz and Holbrook 1991). The functional significance of wider rays in these seven Piper species needs to be checked.

In the present study, we found that deeply furrowed xylem in $P$. betle was produced from parenchyma proliferation (Fig. 1c). This deeply furrowed xylem cambial variant has not been reported previously. Twenty-two families develop xylem in plates (also called radiating 
plate xylem), including Piperaceae. Carlquist (2001) stated that in Piperaceae, combinations of cambial variants were common, such as secondary growth of external primary vascular bundles combined with xylem in plates, so two cylinders of vascular bundles combined with deeply furrow xylem and xylem in plates in $P$. betle is another special cambial variant type. In the stems we examined, the xylem was beginning to furrow in $P$. kadsura, $P$. sintenense, and $P$. taiwanense, indicated that these three species will develop deeply furrowed xylem in older stems. In summary, the seven Piper species in Taiwan produce cambial activity that results in large, radially extended regions of secondary vascular tissues, which are separated from each other by wide, medullary rays of primary parenchyma.

\section{Conclusions}

The arrangement of two concentric cycles of bundles separated by a sclerenchymatous ring is typical of Piper in Taiwan. The genus displays a cambial variant with external primary vascular bundles combined with xylem in plates and wide medullary rays. The stems of these seven species are irregular in conformation and generally oblate, or flattened in cross section. A continuous sclerenchymatous ring is present in all species except $P$. betle, where it is discontinuous, with an additional ring of mucilage canals. The mucilage canals varied from absent, central in the pith, or present in the pith and inner cortex; mucilage canals may be diagnostic for certain species. The deeply furrowed xylem cambial variant only appears in P. betle and is characterized by an interfascicular cambium that forms secondary parenchyma.

\section{Additional file}

Additional file 1: Appendix. Terminologies of transverse section of stems in the family Piperaceae.

\section{Authors' contributions \\ SZY conceived of and designed the experiments. PHC conducted the fieldwork and collected the plant specimens and performed the taxonomi- cal study. SZY wrote the paper. Both authors read and approved the final manuscript}

\section{Acknowledgements}

The authors are extremely grateful to two reviewers who provided suggestions on improving this manuscript. We thank the staff members of PPI and Miss Yi-Xuan Sung for assistance with lianas specimen collection and photography.

\section{Competing interests}

The authors declare that they have no competing interests.

Received: 20 August 2016 Accepted: 19 March 2017

Published online: 29 March 2017

\section{References}

Acevedo-Rodríguez P (2005) Vines and climbing plants of Puerto Rico and the Virgin Islands. The United States National Herbarium Vol. 51, vol 51. Department of Botany, National Museum of Natural History, Washington, DC

Albiero ALM, Paoll AAS, Souza LA, Mourão KSM (2005a) Morfoanatomia dosórgãos vegetativos de Piper crassinervium H.B. \& K. (Piperaceae). Acta Bot Bras 19:305-312

Albiero ALM, Souza LA, Mourão KSM, Almeida OJG, Lopes WAL (2005b) Morfo-anatomia do caule e da folha de Piper gaudichaudianum Kuntze (Piperaceae). Acta Farm Bom 24:550-554

Albiero ALM, Paoli AAS, Souza LA, Mourão KSM (2006) Morfoanatomia dosórgãos vegetativos de Piper hispidum Sw. (Piperaceae). Rev Bras Farmacogn 16:379-391

Angyalossy V, Angeles G, Pace MR, Lima AC, Dias-Leme CL, Lohmann LG, Madero-Vega C (2012) An overview of the anatomy, development and evolution of the vascular system of lianas. Plant Ecol Divers 5(2):167-182

Angyalossy V, Pace MR, Lima AC (2015) Liana anatomy: a broad perspective on structural evolution of the vascular system. In: Schnitzer SA, Bongers F, Burnham RJ, Putz FE (eds) Ecology of lianas. Wiley, West Sussex, pp 254-287

Beck CB (2011) An introduction to plant structure and development: plant anatomy for the twenty-first century, 2nd edn. Cambridge University Press, Cambridge

Caballé G (1993) Liana structure, function and selection: a comparative study of xylem cylinders of tropical rainforest species in Africa and America. Bot J Linn Soc 113(1):41-60

Carlquist S (1991) Anatomy of vine and liana stems: a review and synthesis. In: Putz FE, Mooney HA (eds) The biology of vines. Cambridge University Press, Cambridge, pp 53-71

Carlquist S (2001) Comparative wood anatomy: systematic, ecological, and evolutionary aspects of dicotyledon wood. Springer, Berlin

Carlquist S (2013) Interxylary phloem: diversity and functions. Brittonia 65:477-495

Chen CF, Chen PH, Yang SZ (2013) Climbing modes of climbers in central and southern regions of Taiwan. Q J Chin For 46:441-460 (In Chinese with English abstract)

Chiang SH (1973) Anatomy of plants. National Institute for Compilation and Translation, Taipei

Christenhusz MJM, Byng JW (2016) The number of known plants species in the world and its annual increase. Phytotaxa 261(3):201-217

Duarte MR, Siebenrock MCN (2010) Caracteres anatômicos de folha e caule de Piper mikanianum (Kunth) Steud., Piperaceae. Lat Am J Pharm 29:45-51

Ferreira T, Rasband W (2011) The ImageJ user quide version 1.44. http:// rsbweb.nih.gov/ij/docs/user-guide.pdf. Accessed 02 Oct 2012

Hsu TC, Chung SW (2016) Piper sarmentosum (Piperaceae), a newly naturalized plant in Taiwan. Q J For Res 38(1):1-4

Isnard SI, Silk WK (2009) Moving with climbing plants from Charles Darwin's time into the 21st century. Am J Bot 96(7):1205-1221

Isnard S, Speck T, Rowe NP (2003) Mechanical architecture and development in Clematis: implications for canalised evolution of growth forms. New Phytol 158:543-559

Jacques FMB, de Franceschi D (2007) Menispermaceae wood anatomy and cambial variants. IAWA J 28(2):139-172

Lin TT, Lu SY (1996) Piperaceae. In: Huang TC (ed) Flora of Taiwan, vol 2 , 2nd edn., Department of BotanyNational Taiwan University, Taipei, pp 624-631

Mabberley DJ (2008) Mabberley's plant-book: a portable dictionary of plants, their classification and uses, 3rd edn. Cambridge University Press, Cambridge

Metcalfe CR, Chalk L (1979) Systematic anatomy of the leaf and stem, with a brief history of the subject. Anatomy of the dicotyledons, vol 1, vol 1 . Oxford University Press, New York

Metcalfe CR, Chalk L (1985) Wood structure and conclusion of the general introduction Anatomy of the dicotyledons, 2nd edn. Oxford University Press, New York

Obaton M (1960) Les lianes ligneuses à structure anomales des forêts denses d'Afrique occidentale. Ann Sci Nat Bot 1:1-220 
Pessini GL, Holetz FB, Sanches NR, Cortez DAG, Filho BD, Nakamura CV (2003) Avaliação da atividade antibacteriana e antifúngica de extratos de plantas utilizados na medicina popular. Rev Bras Farmacogn 13:21-24

Putz FE, Holbrook NM (1991) Biomechanical studies of vines. In: Putz FE, Mooney HA (eds) The biology of vines. Cambridge University Press, Cambridge, pp 73-97

Raman V, Galal AM, Khan IA (2012) An investigation of the vegetative anatomy of Piper sarmentosum, and a comparison with the anatomy of Piper betle (Piperaceae) Am J. Plant Sci 3:1135-1144. doi:10.4236/ajps.2012.38137

Ravindran PN, Remarshree AB (1998) Anatomy of Piper colubrinum link. J Spices Aromat Crops 7:111-123

Santos VLP, Franco CRC, Amano E, Messias-Reason IJ, Budel JM (2015) Anatomical investigations of Piper amalago (jaborandi-manso) for the quality control. Braz J Pharmacog 25:85-91

Saraswathy A, Amala K, Vidhya B (2013) Pharmacognostical investigation of Piper retrofractum Vahl. stem (chavya) and its comparison with south Indian market sample. Int J Adv Pharm Res 4(3):1494-1501

Schnitzer SA, Bongers F (2002) Ecology of lianas and their role in forests. Trends Ecol Evol 17(5):223-230
Souza LA, Moscheta IS, Oliveira JHG (2004) Comparative morphology and anatomy of the leaf and stem of Peperomia dah/stedtii, Ottonia martiana and Piper diospyrifolium (Piperaceae). Gayana Bot 6:6-17

Souza LA, Albiero ALM, Almeida OJG, Lopes WAL, Mourão KSM, Moscheta IS (2009) Estudo morfo-anatômico da folha e do caule de Piper arboreum Aubl. (Piperaceae). Lat Am J Pharm 28:103-107

Systematic Association Committee for Descriptive Terminology II (1962) Terminology of simple symmetrical plane shapes (Ch I). Taxon 11(5):145-156

Tepe EJ, Vincent MA, Watson LE (2007) Stem diversity, cauline domatia, and the evolution of ant-plant associations in Piper sect. Macrostachys (Piperaceae). Am J Bot 94(1):1-11

Trueba S, Rowe NP, Neinhuis C, Wanke S, Wagner ST, Isnard S (2015) Stem anatomy and the evolution of woodiness in Piperales. J Plant Sci 176(5):468-485

Yang SZ, Chen PH (2015) Classifying Taiwan lianas with radiating plates of xylem. Taiwania 60(4):151-159. doi:10.6165/tai.2015.60.151

\section{Submit your manuscript to a SpringerOpen ${ }^{\circ}$ journal and benefit from:}

- Convenient online submission

- Rigorous peer review

- Immediate publication on acceptance

- Open access: articles freely available online

- High visibility within the field

- Retaining the copyright to your article 